\title{
RESILIENCE INTERVENTION TO STRENGTHEN SELF-REGULATION IN ADOLESCENT STUDENTS WITH HEARING LOSS ${ }^{* *}$
}

(Received: 10 September 2020; accepted: 31 July 2021)

\begin{abstract}
Background: The importance of strong self-regulation (SR) abilities for academic and social success is known, yet relatively few studies examine students' SR and how it can be promoted especially in adolescents with special needs, such as those students with hearing loss. The purpose of this study was to determine whether a resilience intervention program enhances SR in adolescents with hearing loss.

Methods: This study was experimental with a pre-test, post-test, follow up and control group design. Participants included 122 students with hearing loss in mainstream settings randomly assigned to intervention and control groups (61 students in each group). The interventional group had training for six weeks (two times per week for $75 \mathrm{~min}$ ). The Adolescent Self-Regulatory Inventory was used to measure the self-regulation of students.

Results: The results indicated a significant difference between the control and interventional groups in SR, short SR, and Long SR after the intervention, at both the 6-week and 14-week measurements $(\mathrm{p}<0.001)$.

Conclusion: This study's findings indicate that implementing resilience intervention programs can promote the self-regulation skills in adolescent students with hearing loss.
\end{abstract}

Key words: resilience; self-regulation; hearing loss; adolescents

* Correspondence: Nikta Hatamizadeh, Department of Rehabilitation Management, Pediatric Neurorehabilitation Research Center, University of Social Welfare and Rehabilitation Sciences, Koodakyar Ave, Daneshjoo Blv, Evin, Tehran, Iran. Postcode: 1985713871; nikta_h@yahoo.com.

** The ethics committee of the University of Social Welfare and Rehabilitation Sciences approved the study (Ethical approval number: IR.USWR.REC. 1396.212). 


\section{Introduction}

Hearing loss is a widespread condition, affecting 32 million (9\%) of the world's children and 360 million adults (5.3\%) (World Health Organization 2012). A systematic review on otologic and non-otologic hearing impairment in school-aged children and adolescents reported the prevalence between $0.88 \%$ and $46.70 \%$ (Nunes et al. 2019). The prevalence of unilateral hearing loss in US adolescents aged $12-19$ increased from $14.9 \%$ in $1988-1994$ to $19.5 \%$ in $2005-2006$. The families below poverty levels are more likely to have a family member with hearing loss $23.6 \%$ more than those above the threshold 18.4\% (SHARGORODSKY et al. 2010). A number of studies reported a range of mental health, social, and communication problems in children and adolescents with hearing loss (BROWN \& Cornes 2015; Stevenson et al. 2015; Stevenson et al. 2017: Fellinger et al. 2012; McCarthy-Jones \& Fernyhough 2011; KNUtson \& LANSing 1990). Inadequate communication strategies and poor accommodations in individuals with hearing loss are associated with some psychological problems (KNUTSON \& LANSING 1990). An increased level of mental health problems (social, emotional, and mental well-being) were reported by adolescent students with hearing loss who were studying in a range of educational settings, and who had varying degrees of hearing impairments, and who used a range of communication modes. The analysis showed that the language used at home was a significant predictor of mental health problems (BROWN \& CORNES 2015). A meta-analysis study showed that children and adolescents with hearing loss experience more emotional and behavioral difficulties than their normal-hearing peers (STEVENSON et al. 2017), and in teenagers, poor receptive language ability can lead to elevated emotional behavioral disorders (STEVENSON et al. 2017).

Language serves as a self-regulatory function by guiding goal-directed behavior to facilitate problem solving (VYGOTSKY 1962). The use of self-directed speech which was mentioned by VYGOTSKY means to guide one's behavior doing difficult tasks. Language ability is important for the development of problem solving and regulatory skills. Children with better language skills can use inner speech as a self-guiding tool and show earlier internalization of private speech and regulatory mechanisms, resulting in better self-regulation and adjustment (VALlotTon \& Ayoub 2011). Individuals with hearing loss use the inner speech but may imply receiving less feedback from their surroundings due to the lack of auditory input. Inner conversations might compensate for this lack and assist self-reinforcement. Thus, a need for self-encouragement in the face of mostly ignorant surroundings seems necessary. For the person with hearing loss, an inner dialogue, employed in a positive and supportive way might be more important (ZIMMERMANN \& BRUGGER 2013). Speech skills and vocabulary impact social inclusion (CONSTANTINESCU et al. 2015), and for children with hearing loss, 
this condition results in more limited opportunities for effective and satisfying interaction (MoORes 2001; Quigley \& PAUl 1994). The experiences of students in inclusive settings indicate that during their attendance in these schools they bear a feeling of marginalization and isolation because they can not communicate easily with their peers (ANGELIDES \& ARAVI 2007).

In North America, about $60-80 \%$ of students with hearing loss attend inclusive schools alongside normal-hearing pupils (TYE-MurRAY et al. 2014; BORDERS et al. 2010). Children and adolescents with hearing loss as well as their parents and teachers believe that in a successful inclusion of learners with hearing impairments, it is important to consider some factors that are: child-related, family involvement and use of technology (for example, use of hearing assistive devices for auditory stimulation), focusing on inclusion and specifically school and educational factors (teacher training and preparedness, school settings, instructional strategies and classroom management for student engagement). The significance of other factors such as communicating with specialists (specially getting information from medical professionals about cochlear implants and using assistive technologies) and the assessment of support technology, which relates to the assessment of resources such as visual supports, digital boards, and representations with images (ROSA \& ANGULO 2019; Collair 2001; EriKs-Brophy et al. 2006) is highlighted too. One of the goals in inclusive education is to facilitate academic and social success for students with hearing loss. A good inclusive classroom should facilitate cooperative learning, endorse participation and collaboration, encourage the expression of thoughts and behaviors, promote self-regulation (SR), and foster the development of social and emotional skills (MARTin et al. 2017; Rimm-KaUfMan et al. 2006; Rimm-KaUfMAN \& CHIU 2007).

Self-regulation is defined as an ability to activate, monitor, and inhibit behavior, attention, emotions, or cognitive processes, also responding to internal or external stimuli in a flexible and adjustable way to achieve the desired outcomes (Demetriou 2000; Moilanen 2007). High levels of self-regulation are linked to prosocial behavior and academic achievement; prosocial adolescents are more likely to have greater self-efficacy in regulating risky behavior, managing negative emotions, and expressing positive emotions (BANDURa et al. 2003). MoILANEn and colleagues (2009, as cited in Diss et al. 2014) believe in evaluating the regulation of objectives in the most immediate or short-term, which could be functionalized as the control of attention, control of impulses, and emotional control or regulation of the immediate context. However, attention to long-term components of self-regulation is important too (MOILANEN 2007). The long-term self-regulation considers a component of SR such as impulse control for a period of time: several weeks, months, or years (for example, when an adolescent takes a course to achieve career goals, or keeps saving money to buy an expensive object). This aspect of SR has been addressed in studies about school performance (BILDE et al. 2011; 
MiLler \& Brickman 2004) or health behaviors (HaLl \& Fong 2007; Zimbardo \& BOYD 1999).

The adolescence phase is a period when individuals experience peer, family, academic, and career stress as well as other individual challenges (ZIMMER-GEMBECK \& SKINNER 2008). The effects of stress on coping and psychological functioning are important because recurrent stressors may tax an adolescent's self-regulatory skills. Difficulties with self-regulation in adolescents showcases the emergence of a range of developmental outcomes, such as internalizing and externalizing problems, alcohol and substance use problems, low empathy, and issues with social and academic competence (EISENBERG et al. 2003; KrUEGER et al. 2002; MisCHeL et al. 1988). The study of KING and colleagues (2013) indicated that the individual's development of effortful control (executive attention regulation and inhibitory control) and impulsivity (speed of response initiation) which are the core aspects of self-regulation (RoTHBAR et al. 2001) in childhood, is linked to differential outcomes in adolescents. Lower impulsivity and higher levels of effortful control are related to a decline in externalizing and internalizing problems and a higher social competence, as well as well-being. The individual variability in the development of impulsivity is unrelated to behavior problems, competence, and well-being, which means changes during other developmental periods may be more critical than in the pre-adolescent period. However, the changes over time across effortful control determine the variation in adjustment over and above the effects of earlier individual differences. Development of self-regulation is the key for successful adaptation in childhood and adolescence. Adaptation depends on managing emotions, regulating and directing behaviors, thinking constructively, and acting on the environment to change or decrease the sources of stress (COMPAS et al. 2001; Zimmer-GEMBECK \& SKINNER 2011). Therefore, adolescents' self-regulatory abilities play an important role in this phase in terms of their functioning, resilience, and overall well-being (ElLiot et al. 2011; GARDNER et al. 2008; Hofer et al. 2011).

Resilience refers to a dynamic process wherein individuals show positive adaptation despite experiences of significant adversity (LUTHAR et al. 2000; MASTEN 1999). The effect of risk and protective factors on resilience has been studied. Risk factors are all stressful life events that may increase the onset of a problem or maintain the problem (RUTTER 1985). Protective factors work as a dynamic mechanism that helps children to resist or balance the risks which they are facing (RUTTER 1985; 2012). High intelligence, development of appropriate coping strategies, optimism, problem-solving, self-regulation are factors which act to protect individuals against adverse situations (GARcia-VesGa \& Domíngues De La Ossa 2013; Zolkoski \& BULLOCK 2012).

Students with hearing loss may be at risk for poor self-regulation compared to their normal-hearing peers. The development of SR requires effective communication through social interactions with others (BODROVA \& LEONG 2008; ZIMMERMAN 
1995). Therefore, the language and communication delays in children with hearing loss may contribute to a deficit in SR. They have more emotional and behavioral difficulties than their normal-hearing peers (KIRMAn \& SARI 2013; Coll et al. 2009; DAmmeyer 2009; Vostanis et al. 2007) and are rated as more impulsive and with lower inhibitory control (GREENBERG \& KUSCHÉ 1998). Self-regulation is closely related to emotional competency, which has an important role in social and academic success (Denham 2006; SAWYer et al. 2014). Children with hearing loss experience difficulties with their competency (HATAMIZADEH et al. 2008), and since children use the skills of emotional competence to regulate their emotions, these youngsters experience problems with emotional regulation that is a core component of self-regulation (MURRAY et al. 2015).

There is much evidence that SR plays an important role in developing and maintaining physical health and well-being over one's lifespan (BIERMAN et al. 2008; Galla \& Duckworth 2015; Moffitt et al. 2011). The ability to work toward a desired outcome while controlling whatever impulses that could arise seems to be an idea shared by differing definitions of self-regulation (MARTIN \& McLellan 2008; Neal \& Carey 2005). This can be relevant to resilience if managing personal challenges are accounted for in adjustments to life pathways (BUCKNER et al. 2009; GeSTSDOTTIR \& LERNER 2008). A comprehensive review of self-regulation interventions from birth through young adulthood shows that positive and meaningful changes can result from several different intervention approaches, conflict resolution, stress management, coping, resiliency training, mind-body and mindfulness interventions (MurRaY et al. 2016). Some believe that language ability skills can serve as a predictor of self-regulation. SR is defined as a construct encompassing cognitive, physiological, emotional, and behavioral regulatory processes that promote adaptive or goal-directed behavior (BERGER 2011; CALKINS \& Fox 2002). Interventions focusing on training the language and communication, social, and emotional skills can facilitate self-regulation in an individual. Considering the importance of SR skills, appropriate interventions seem necessary when children with hearing loss are likely to experience difficulties in managing their emotions and behaviors in stressful situations.

There are not many studies focusing on interventions for enhancing self-regulation in adolescents with hearing loss. Most studies in this area are focused on social and emotional interventions that in a way could promote self-regulation too (Bonillo 2017; LucKner \& Sebald 2013; LuCKner \& MovahedaZARHouligh 2019). Proper intervention can assist children in developing more adaptive and proceduralized strategies for self-regulation. This study adapted a resilience program (teaching social, emotional, positive self-talk, communication, problem solving, coping, and interpersonal skills) for children with hearing loss, and delivered it through explicit teaching. Also, since not much research exists that evaluated the effectiveness of resilience interventions in adolescents with hearing loss, this study's 
aim was to determine the effect of a resilience intervention program that addresses the needs of adolescent students with hearing loss to learn and practice behavioral and cognitive skills designed to strengthen their self-regulation.

\section{Method}

This study was experimental with a pre-test, post-test, follow up and control group design.

\subsection{Participants}

The Education Ministry introduced 298 students (6th to 9th grades) with hearing loss studying in public inclusive schools for this study, in which 34 were not included because the schools, parents, or the students themselves did not agree to participate. Of the 264 who agreed to participate, 125 were randomly included in the study, three of which did not continue the program. They did not have any other disabilities (reported in their documents). The sample consisted of 74 boys and 48 girls. Without using hearing aids, the severity of hearing loss in 20 students was mild, in 85 it was moderate and in 17 it was in the moderate to severe range. By using hearing aids, the corrected hearing thresholds in the better ear of 83 students were within the mild, 24 in the moderate, and 15 in the moderate to severe range of hearing loss. The participants used hearing aids and some had cochlear implants. They used audio verbal communication. The cause of hearing loss for 106 students was congenital and for 16 was acquired. The participants were studying in public schools (there are two kinds of schools in which students with hearing loss could attend; public and private ones), and their socio-economic level was almost identical.

Informed parental and student consents were obtained and participants were assigned to experimental and control groups randomly across the schools. This is presented in Figure 1. 


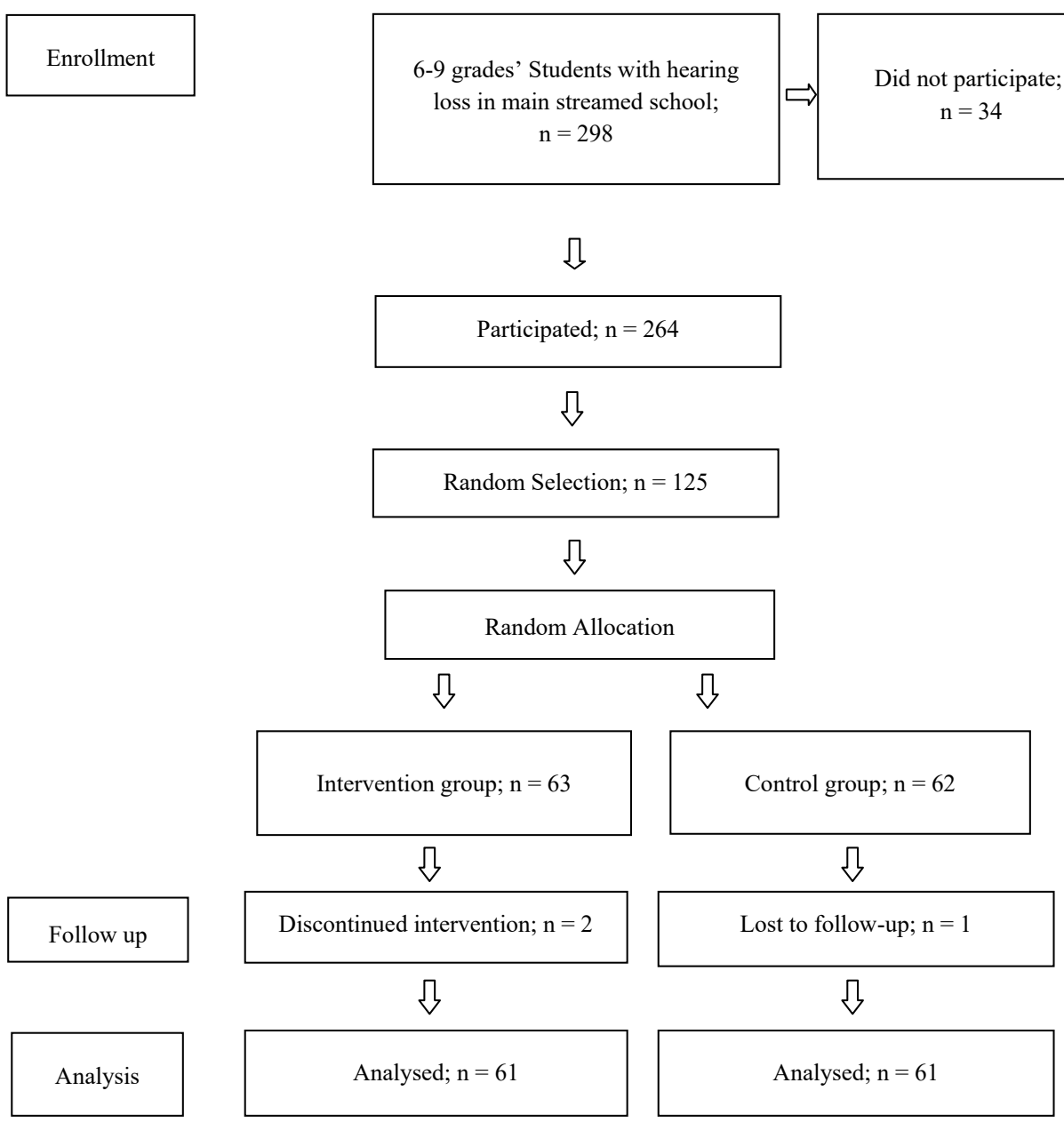

\section{Figure 1}

Flow diagram

\subsection{Measures}

The Self-regulation Scale: Adolescent Self-Regulatory Inventory (MoILANEN 2007) contains 36 items which measure adolescents' ability to activate, monitor, maintain, inhibit, and adapt their emotions, thoughts, attention, and behavior. It assesses adolescent short-term self-regulation (dimension relates to impulse, attention and emotional regulation) toward immediate objectives, and long-term self-regulation 
dimension (efforts to control impulse, attention, and emotional regulation) toward objectives that cover a longer period (as career goals, saving money, etc.). For measuring short-term self-regulation (Short SR), 13 items should be considered, for long-term self-regulation (Long SR) 14 items, and the remaining nine items are added to short and long self-regulation for measuring the overall self-regulation (SR). Rating of each item is based on the Likert type, ranging from 1 (not at all true for me) to 5 (really true for me). The reliability analyses for adolescent self-report on short and long-term self-regulation was reported: short-term; $\alpha=0.75$ and longterm; $\alpha=0.80$. In this study, $\alpha=0.77$ was for self-regulation. The measurements for long and short-term self-regulation were $\alpha=0.82$ and $\alpha=0.73$.

A brief questionnaire that included demographic data on age, gender, grade, the severity of hearing loss and using hearing assistive devices, was used.

Pre-test measurements were administered just before the intervention, the post-tests were completed at the end of the intervention (six weeks later), and finally, the follow-up tests were completed (eight weeks after the post-test).

\subsection{Intervention}

The resilience intervention program was carried out by itinerant teachers and aimed at promoting the developmental integration of emotions, feelings, cognitive and behavioral skills. For the training, groups of 3-5 students were arranged based on school distances. The program was delivered in 12 sessions of 75 minutes each, twice a week for six weeks. The control group did not have the intervention during the program and attended the usual school curriculum. Considering the ethical issues, after finishing the program, the control group had the intervention in a shorter time. Both groups did not have any such intervention (psychological interventions) during and nine months previous to this program.

A review of resilience programs in the literature, such as the Penn Resiliency Program; (PRP) (SEligman et al. 2009), Resourceful Adolescent Program (RAPA) (Shochet et al. 2004), Promoting Alternative Thinking Strategies (PATHS) (GreEnberg \& Kusché 1998) and the Aussie Optimism Resilience-focused Program (AORSP) (GILmORE et al. 2014), helped us to develop and adapt the program for hearing-loss students. To facilitate learning for students with hearing loss, lots of visual stimulation (pictures and drawings, pictured story books, role playing and games) were used in teaching the skills. The objectives of the lessons were mostly influenced by AORSP, since it is based on SELIGMAN's theory of Positive Psychology and Penn Resiliency Program. AORSP was applied for students with intellectual disabilities and one of the professors in the study assisted us with this program.

The Penn Resiliency Program, which is the basis of this intervention program, validated skills that build cognitive and emotional fitness, strength of character, and strong relationships. Each skill targets one or more of the resilience competencies 
(Murray et al. 2016). Some of the competencies are: self-awareness (the ability to pay attention to your thoughts, emotions, behavior, and physiological reactions), self-regulation (the ability to change one's thoughts, emotions, behavior, and physiology for a desired outcome), mental ability (the ability to look at situation from multiple perspectives and to think creatively and flexibly), strengths of character (the ability to use one's strengths to engage authentically, overcome challenges, and build a life aligned with one's values), connection and communication (the ability to build and maintain trusting relationships), problem solving (fight biases in thinking, accurately identify the causes of problem and find solutions), as well as optimism (the ability to understand and expect the positive to focus on what you can control, and take purposeful action). To achieve some of these competencies, the aim of this program was for the participants to understand and use the related skills appropriately in different situations. Thus, the subjects of the program's sessions were arranged for teaching about: feelings, styles of thinking (positive, negative) and the link between thoughts and feelings, coping strategies, strengths and weaknesses, problem-solving, communication skills, social skills, negotiation, despising and ridiculing, as well as intrapersonal and interpersonal skills. The intervention package contained two booklets; for the itinerant teacher (a special teacher for students with hearing loss) and for the student. The teacher's booklet consisted of 12 modules (each includes the aim and an introduction, the instruments she/he needs (for example student's booklet, black- or whiteboard, storybooks for some sessions, etc.), the time needed for each activity, the manual for teaching and doing activities with students, and a page of short information for parents to observe and possibly follow the thought skills and practices. The student's booklet included 12 modules with individual activities (such as answering the questions in the booklet, drawing, etc.) and group activities (discussing the subject or question that the teacher asks, playing games, role-playing, etc.). More description of the sessions is in a complementary file (ADIBSERESHKI et al. 2019).

\subsection{Data analysis}

The Kolmogorov-Smirnov test was used to examine the normality of the SR scores' distribution (Table 2). Normally, distributed scores were analyzed with the t-test and non-normal ones with the Mann-Whitney test.

\section{Results}

The ages of the participants (122 students) ranged between 12 to 15 . The mean and standard deviation was $13.65 \pm 1.00$ and the ratio for gender was $3 / 2$ ( 74 boys and 48 girls). There was no significant difference between the groups in age and gender. Of all students, 78 (51.6\%) used a hearing aid in one ear, 44 (36.1\%) in both ears, 
and $8(6.6 \%)$ students used cochlear implants. Most of the participants, $83(68 \%)$ were within the mild, and the rest, $24(19.7 \%)$ in the moderate, while $15(12.3 \%)$ were in the moderate severe range of hearing loss. The American Speech-language Hearing Association's (ASHA, 2015) classification was used for identifying the degree of hearing loss; normal (10-15), slight (16-25), mild (26-40), moderate (41-55), moderately severe (56-70), severe (71-90), and profound (91+).

Table 1 shows the mean scores of interventional and control groups in $\mathrm{T} 1$, T2, T3; before the intervention, after the intervention (six weeks after starting intervention) and follow-up (14 weeks after starting intervention). The mean score of the interventional group was increased from $\mathrm{T}=98.74 \pm 12.27$ to $\mathrm{T} 2=108.44 \pm$ 8.21 and $\mathrm{T} 3=107.93$. Also, the mean scores of the interventional group in $\mathrm{T} 2$ and T3 were higher than in the control group.

Table 1

Mean scores in intervention and control groups

\begin{tabular}{lcccccc}
\hline & \multicolumn{3}{c}{ Intervention } & & \multicolumn{3}{c}{ Control } \\
& \multicolumn{3}{c}{ Mean \pm SD } & & \multicolumn{3}{c}{ Mean \pm SD } \\
& $T 1$ & $T 2$ & $T 3$ & $T 1$ & $T 3$ \\
\hline SR & $98.74 \pm 12.27$ & $108.44 \pm 8.21$ & $107.9 \pm 7.84$ & $97.69 \pm 14.24$ & $98.51 \pm 14.36$ & $98.06 \pm 7.08$ \\
Short SR & $35.08 \pm 5.57$ & $39.92 \pm 4.15$ & $39.57 \pm 4.72$ & $35.72 \pm 7.15$ & $36.36 \pm 7.16$ & $36.30 \pm 4.17$ \\
Long SR & $37.64 \pm 7.81$ & $43.60 \pm 6.16$ & $42.93 \pm 4.72$ & $39.95 \pm 6.06$ & $38.13 \pm 6.09$ & $38.08 \pm 4.57$ \\
\hline
\end{tabular}

Table 2 displays a one-sample Kolmogorov-Smirnov test for normality of data distribution. The follow-pre scores in two groups of experiment and control were normal, with the T-test was used for data analysis. The scores in post-pre scores were not normal and the Mann-Whitney test was used.

Table 2

One-Sample Kolmogorov-Smirnov test for normality of data distribution

\begin{tabular}{lcccccc}
\hline Group & $\begin{array}{c}\text { Post-Pre SR } \\
\text { scores }\end{array}$ & $\begin{array}{c}\text { Follow-Pre SR } \\
\text { scores }\end{array}$ & $\begin{array}{c}\text { Post-Pre Short } \\
\text { SR scores }\end{array}$ & $\begin{array}{c}\text { Follow-Pre } \\
\text { Short SR scores }\end{array}$ & $\begin{array}{c}\text { Post-Pre Long } \\
\text { SR scores }\end{array}$ & $\begin{array}{c}\text { Follow-Pre Long } \\
\text { SR scores }\end{array}$ \\
\hline Intervention & $\mathrm{P}=0.605$ & $\mathrm{P}=0.484$ & $\mathrm{P}=0.312$ & $\mathrm{P}=0.270$ & $\mathrm{P}=0.421$ & $\mathrm{P}=0.230$ \\
Control & $\mathrm{P}=0.001$ & $\mathrm{P}=0.876$ & $\mathrm{P}<0.001$ & $\mathrm{P}=0.347$ & $\mathrm{P}<0.001$ & $\mathrm{P}=0.883$ \\
\hline
\end{tabular}


The mean differences in the scores for the pre-test, post-test, of SR, short SR and long SR in two groups of intervention and control are shown in Table 3. The mean difference score between the post-test and pre-test of the interventional group was 9.70 and the control group was 0.82 , which indicates a significant increase in the self-regulation of the interventional group $(<0.001)$. Therefore, the intervention was effective for those who participated in the program. The effect sizes were 0.69 , 0.49 , and 0.89 for SR, Short SR and long SR respectively, using Cohen's effect size (Sullivan \& Feinn 2012).

Table 3

Mean difference score between pre-test and post-test of SR, short SR, and long SR

\begin{tabular}{|c|c|c|c|c|}
\hline Variables & Intervention & Control & $E S^{*}$ & $P$-Valuet \\
\hline \multicolumn{5}{|c|}{ Mean $\pm S D$} \\
\hline$S R$ & $9.70 \pm 11.72$ & $0.82 \pm 4.09$ & 0.69 & $<0.001$ \\
\hline Short SR & 4. $84 \pm 7.02$ & $0.64 \pm 2.52$ & 0.49 & $<0.001$ \\
\hline Long SR & $5.95 \pm 8.72$ & $0.18 \pm 3.25$ & 0.89 & $<0.001$ \\
\hline
\end{tabular}

*ES: Effect Size

$\dagger$ Mann-Whitney test.

The mean differences in the scores for the pre-test, follow-up of SR, short SR and long SR in interventional and control groups are shown in Table 4. The mean difference scores for SR, short SR, and long SR in the interventional group are significant in follow-up ( $\mathrm{p}=0.003,0.013$ and 0.001 respectively), which means that the effect of intervention is maintained in follow-up.

\section{Table 4}

Mean difference score between follow-up and pre-test of SR, short SR, and long SR

\begin{tabular}{lcccc}
\hline & Intervention & Control & $t$ & $P$-Value* \\
\multicolumn{2}{c}{ Mean $\pm \mathrm{SD}$} & & \\
\hline SR & $9.20 \pm 15.98$ & $0.38 \pm 16.30$ & 3.017 & 0.003 \\
Short SR & $4.49 \pm 8.53$ & $0.57 \pm 8.57$ & 2.531 & 0.013 \\
Long SR & $5.30 \pm 8.21$ & $0.13 \pm 8.28$ & 3.459 & 0.001 \\
\hline
\end{tabular}

*T-test. 
The mean scores from three time points (T1, T2, and T3) and two groups (intervention vs. control) were also analyzed with 'repeated measure between subjects ANOVA' (mixed method) as a within and between effect, method.

The results showed that in the intervention group, the SR, Short SR, and Long SR mean scores were significantly different between T1, T2 and T3 measurements $(\mathrm{P}<0.001)$. In the control group, no significant differences existed between T1, T2, T3 measurements in each of the SR, Short-SR, or Long SR scores $(P>0.05)$. The Bonferroni post hoc test for paired comparisons in the intervention group showed a significant difference between mean scores in T1-T2 and also between T1-T3 measurements for all of the three dependent variables SR $(\mathrm{P}<0.001)$, Short SR ( $\mathrm{P}$ $<0.001)$ and Long SR $(\mathrm{P}<0.001)$. An overview of the inferential statistics can be seen in Table 5.

\section{Table 5}

An overview of the inferential statistics for the factors Time (baseline, week 6/end of resilience program, weak 14/follow-up) and Group (intervention vs. control), and Self-regulation as dependent variables

\begin{tabular}{|c|c|c|c|c|c|c|c|c|c|c|}
\hline \multirow[t]{2}{*}{$\begin{array}{l}\text { Degree } \\
\text { of freedom }\end{array}$} & \multicolumn{2}{|c|}{$\begin{array}{c}\text { Time } \\
(2,240)\end{array}$} & \multirow[t]{2}{*}{$p$-value } & \multicolumn{2}{|c|}{$\begin{array}{l}\text { Group } \\
(1,120)\end{array}$} & \multirow[t]{2}{*}{$p$-value } & \multicolumn{2}{|c|}{$\begin{array}{l}\text { TimeGroup } \\
\text { Interaction } \\
(2,240)\end{array}$} & \multirow[t]{2}{*}{$p$-value } & \multirow[t]{2}{*}{$\begin{array}{l}\text { Green- } \\
\text { house- } \\
\text { Geisser } \\
\text { Epsilon }\end{array}$} \\
\hline & $F$ & $\eta^{2}$ & & $F$ & $\eta^{2}$ & & $F$ & $\eta^{2}$ & & \\
\hline Self-Regulation & 11.197 & 0.085 & $\mathrm{P}<0.001$ & 23.934 & 0.166 & $\mathrm{P}<0.001$ & 8.631 & 0.067 & $\mathrm{P}=0.001$ & 0.736 \\
\hline $\begin{array}{l}\text { Short } \\
\text { Self-regulation }\end{array}$ & 10.849 & 0.082 & $\mathrm{P}<0.001$ & 9.119 & 0.071 & $\mathrm{P}=0.003$ & 6.423 & 0.051 & $\mathrm{P}=0.004$ & 0.797 \\
\hline $\begin{array}{l}\text { Long } \\
\text { Self-regulation }\end{array}$ & 11.524 & 0.088 & $\mathrm{P}<0.001$ & 19.794 & 0.142 & $\mathrm{P}<0.001$ & 10.295 & 0.079 & $\mathrm{P}<0.001$ & 0.930 \\
\hline
\end{tabular}

\section{Discussion}

The findings of this study indicate that the participants in the experimental group made greater gains in comparison to those in the control group in self-regulation and its two dimensions: long and short term self-regulations. Promotion of self-regulation or related domains, using various interventional programs, is reported (BurcKhardT 2017; LuCKNER \& SEBALD 2013; LuCKNER \& MovaHEDAZARHOUligh 2019; Soleimanieh et al. 2013; Lakes \& Hoyt 2004; Minnaert et al. 2017; Smith et al. 2017; Tominey \& MCClelland 2011; Westhues et al. 2009). The present study considered two dimensions of self-regulation for measurement, and other research into different interventions might look at other aspects of self-regulation. 
For example, the study (BURCKHARDT 2017) done for children and adolescents with special needs indicated different results. The mindfulness curriculum was applied for autism, learning disabilities, and other health disorders and the result showed no significant effect on the self-regulation of students even though positive outcomes occurred for managing stress and anxiety, greater focus and attention, better conflict management, and increased self-compassion. LUCKNER and SEBALD (2013), in their study about promoting the self-determination of students with hearing impairment, stated that self-determination enables individuals to make choices and engage in goal-directed, self-regulated behavior. They assert that even though paucity of research or attention has been directed to this construct in students with hearing loss, making opportunities and practicing the activities related to self-determination appropriate interventions seem necessary when these would help promote this skill in students. They concluded that teaching the component elements of social-determination provides students with strategies to set goals, solve problems, work toward achieving goals, and helps them develop the ability to be responsible and take control of their lives. LUCKNER and MOVAHEDAZARHOULIGH (2019), did a research synthesis on social-emotional interventions with children and youth who are deaf or hard of hearing and stated that social-emotional interventions play an important role on emotional well-being and emotional health effects of social interaction. The study suggests that explicit instruction in social skills may be beneficial for students who are deaf or hard of hearing. In the present study, the teaching of social, communicational, interpersonal and emotional skills was considered in some of the programs' lessons. Some skills that students learned were: how can they express their feelings and emotions, respect for others' feelings, to start or continue a relationship, getting along with their peers and other people, expressing their needs and getting help when they need it. As the importance of explicit instruction in teaching is determined by studies, and perhaps students with disabilities may require significant differences in treatment when using the interventions, this study used explicit teaching, focused on SR-related knowledge and skills in the curriculum. Therefore, positive outcomes of the present study lead us to the conclusion that the program was well planned and instructed to its aim, which was promoting self-regulation skills of adolescent students with hearing loss. Even though such experimental or quasi-experimental studies in interventional programs promoting self-regulation in adolescents with hearing loss were not found, comparing the effect size of the present study $(d=0.69)$ to other interventional studies on enhancing self-regulation in children and adolescents without disability, indicates a large effect of the resilience intervention; thus the effectiveness of this program. PANDEY and colleagues (2018) found that the overall effect of 42 intervention on SR was statistically significant and favored the intervention (pooled effect size $\mathrm{d}=0.42 ; 95 \% \mathrm{CI}, 0.32-0.53$ ). The social and personal skills interventions had a higher mean effect size $(\mathrm{d}=0.64 ; 95 \% \mathrm{CI}, 0.42-0.86)$. 
The scores of post-test and follow-up in this study indicated that students in the intervention group had a significant improvement in short - and even more in long term - self-regulation. A study (OrIOL et al. 2017) also found high scores of self-control (short and long term) in adolescents. Short and long-term self-regulation is associated with all indicators of adjustment. Higher levels of both forms of self-regulation are associated with higher levels of prosocial behavior and lower levels of behavioral difficulties (MoILANEn 2007); in this study, the program addressed these social, emotional, and behavioral skills. Adolescents seem to have an increased maturation of the prefrontal cortex and are capable of setting goals and long-term plans (BlaKemore et al. 2007). However, sometimes adolescents set goals which could be more induced by extrinsic motivations such as social pressure than intrinsic motivations (WONG \& CsiKszentminalyi 1991), and cause them tedious and frustrating feelings. During puberty, adolescents may have a lot of trouble controlling their impulses and make proper decisions when their objective involves emotional components (BELL \& MCBRIDE 2010). A different result in goal-setting abilities of adolescent students with emotional and behavioral disorders was found in a study (SMiтh et al. 2017). The study showed no evidence of the intervention curriculum (I Control) affecting students' self-reported goal setting. The insufficient time for the gains in knowledge to transfer to goal-setting skill development could be the reason for having such a result.

The results of the present study support the effectiveness of a resilience intervention program on the self-regulation skills of children with hearing loss. The outcomes have thrilling and important suggestions for educators and mental health professionals interested in promoting positive youth development. Self-regulatory abilities can be taught to a broad range of children with different abilities, and in ways that are highly attractive. The interventions can be interesting, enjoyable, challenging, and rewarding while attaining the objective of increasing self-regulatory abilities.

This study has a few limitations. The use of the self-reporting form of measurement could have affected the results. The answers may be exaggerated, or an individual may be embarrassed to reveal private details, and different biases can affect the findings. Future research can address this by using assessment instruments completed by parents/teachers and/or professional observers. Also, the participants were from public inclusive schools in a large city and the results cannot be generalized to other students with hearing loss in different settings and situations. Lastly, the present research did not consider the impact of resilience intervention on the components of the short term (control of impulses, attention and emotional control or regulation of the immediate context), and long term SR (components of SR for a period of time, several weeks, months, or years for example, an adolescent setting goals and making plans), which can be examined by upcoming studies. 


\section{References}

Adibsereshi, N., N. Hatamizadeh, F. Sajedi \& A. Kazemnejad (2019) 'The Effectiveness of a Resilience Intervention Program on Emotional Intelligence of Adolescent Students with Hearing Loss', Children 6(3), $48-57$ (https://doi. org/10.3390/children6030048).

American Speech-Language-Hearing Association (2015) 'Type, Degree, and Configuration of Hearing Loss', Audiology Information Series, retrieved 21 Sep 2021 from https:/www.asha.org/siteassets/uploadedfiles/ais-hearing-loss-types-degree-configuration.pdf.

Angelides, P. \& C. Aravi (2007) 'The Development of Inclusive Practices as a Result of the Process of Integrating Deaf/Hard of Hearing Students', European Journal of Special Needs Education 22(1), 63-74 (https://doi.org/10.1080/08 856250601082299).

Bandura, A., G.V. Caprara, C. Barbaranelli, M. Gerbino \& C. Pastorelli (2003) 'Role of Affective Self-Regulatory Efficacy in Diverse Spheres of Psychosocial Functioning', Child Development 74 (3), 769-82 (https://doi. org/10.1111/1467-8624.00567).

Bell, C.C. \& D.F. MCbride (2010) 'Affect Regulation and Prevention of Risky Behaviors', JAMA 304(5), 565-66 (https://doi.org/10.1001/jama.2010.1058).

Berger, A. (2011) Self-Regulation: Brain, Cognition, and Development (Washington: American Psychological Association) (https://doi.org/10.1037/12327-000).

Bierman, K.L., R.L. Nix, M.T. Greenberg, C. Blair \& C.E. Domitrovich (2008) 'Executive Functions and School Readiness Intervention: Impact, Moderation, and Mediation in the Head Start REDI Program', Development and Psychopathology 20(3), 821-43 (https://doi.org/10.1017/S0954579408000394).

Bilde, J., M. Vansteenkiste \& W. Lens (2011) 'Understanding the Association Between Future Time Perspective and Self-Regulated Learning Through the Lens of Self-Determination Theory', Learning and Instruction 21 (3), 332-44 (https://doi.org/10.1016/j.learninstruc.2010.03.002).

Blakemore, S.-J., H. Den Ouden, S. Choudhury \& C. Frith (2007) 'Adolescent Development of the Neural Circuitry for Thinking About Intentions', Social Cognitive and Affective Neuroscience 2(2), 130-39 (http://doi.org/10.1093/ scan/nsm009).

Bodrova, E. \& D.J. LeOng (2008) 'Developing Self-Regulation in Kindergarten. Can We Keep All the Crickets in the Basket?', Young Children 63(2), 56-58, retrieved 29 Sep 2021 from http://talkingtogether.com.au/wp-content/uploads/2018/09/ developing-self-regulation-to-get-ready-for-kindergarten.pdf.

Bonillo, D.B. (2017) 'Developing Social-Emotional Competence Interventions that Facilitate Emotional and Behavioral Self-Regulation', Doctor of Education 
(Ed.D) in Leadership Dissertations (Irvine: Concordia University Irvine) retrieved 29 Sep 2021 from http://hdl.handle.net/11414/3276.

Borders, C.M., D. BarnetT \& A.M. Bauer (2010) 'How Are They Really Doing? Observation of Inclusionary Classroom Participation for Children with Mildto-Moderate Deafness', Journal of Deaf Studies and Deaf Education 15(4), 348-57 (https://doi.org/10.1093/deafed/enq028).

Brown, P.M. \& A. Cornes (2015) 'Mental Health of Deaf and Hard-of-Hearing Adolescents: What the Students Say', Deaf Studies and Deaf Education 20(1), 75-81 (https://doi.org/10.1093/deafed/enu031).

Buckner, J.C., E. Mezzappa \& W.R. Beardslee (2009) 'Self-Regulation and its Relations to Adaptive Functioning in Low Income Youths', American Journal of Orthopsychiatry 79(1), 19-30 (https://doi.org/10.1037/a0014796).

BurckhardT, C.B. (2017) 'Mindfulness in the Special Education Classroom: A Mixed Methods Pilot Study of the Learning to Breathe Mindfulness Curriculum', EDT - Doctoral Dissertations (Johns Hopkins University, Baltimore) retrieved 29 Sep 2021 from http://jhir.library.jhu.edu/handle/1774.2/44730.

CAlkins, S.D. \& N.A. Fox (2002) 'Self-Regulatory Processes in Early Personality Development: A Multilevel Approach to the Study of Childhood Social Withdrawal and Aggression', Development and Psychopathology 14(3), 477-98 (https://doi.org/10.1017/S095457940200305X).

Coll, K.M., M.M. Cutler, P. Thobro, R. HaAs \& S. Powell (2009) 'An Exploratory Study of Psychosocial Risk Behaviors of Adolescents Who Are Deaf or Hard of Hearing: Comparisons and Recommendations', American Annals of the Deaf 154(1), 30-35 (https://doi.org/10.1353/aad.0.0074).

Collair, L.J. (2001) Indicators of Successful Inclusion of a Learner Who is Deaf in a Mainstream Class (Med thesis, University of Stellenbosch, South Africa) retrieved 29 Sep 2021 from http://hdl.handle.net/10019.1/52305).

Compas, B.E., J.K. Connor-Smith, H. Saltzman, A.H. Thomsen \& M.E. WadSworth (2001) 'Coping with Stress During Childhood and Adolescence: Problems, Progress, and Potential in Theory and Research', Psychological Bulletin 127(1), 87-127 (https://doi.org/10.1037//0033-2909.127.1.87).

Constantinescu-Sharp, G., R.L. Philips, A. Davis, D. Dornan, A. Hogan (2015) 'Exploring the Impact of Spoken Language on Social Inclusion for Children with Hearing Loss in Listening and Spoken Language Early Intervention', Volta Review 115(2), 153-81, retrieved 29 Sep 2021 from https://researchoutput.csu. edu.au/en/publications/exploring-the-impact-of-spoken-language-on-socialinclusion-for-c.

Dammeyer, J. (2009) 'Psychosocial Development in a Danish Population of Children with Cochlear Implants and Deaf and Hard-of-Hearing Children', Journal of Deaf Studies and Deaf Education 15(1), 50-58 (https://doi.org/10.1093/deafed/ enp024). 
Denham, S.A. (2006) 'Social-Emotional Competence as Support for School Readiness: What Is It and How Do We Assess It?', Early Education and Development 17(1), 57-89 (https://doi.org/10.1207/s15566935eed1701_4).

Demetriou, A. (2000) 'Chapter7 - Organization and Development of Self-Understanding and Self-Regulation: Toward a General Theory' in M. BoEkAERTS, P.R. PINTRICH \& M. ZEIDNER, eds., Handbook of Self-Regulation (Cambridge: Academic Press) 209-51 (https://doi.org/10.1016/B978-012109890-2/50036-6).

Dias, P.C., J.A.G. Del Castillo \& K.L. Moilanen (2014) 'The Adolescent Self-Regulatory Inventory (ASRI) Adaptation to Portuguese Context1', Paidéia (Ribeirao Preto) 24, 58 (https://doi.org/10.1590/1982-43272458201403).

Eisenberg, N., C. Valiente, R.A. Fabes, C.L. Smith, M. Reiser, S.A. Shepard, S.H. Losoya, I.K. Guthrie, B.C. Murphy \& A.J. Cumberland (2003) 'The Relations of Effortful Control and Ego Control to Children's Resiliency and Social Functioning', Developmental Psychology 39(4), 761-76 (https://doi. org/10.1037/0012-1649.39.4.761).

Elliot, A.J., T.M. Thrash \& K. Murayama (2011) 'A longitudinal Analysis of Self-Regulation and Well-Being: Avoidance Personal Goals, Avoidance Coping, Stress Generation, and Subjective Well-Being', Journal of Personality 79(3), 643-74 (https://doi.org/10.1111/j.1467-6494.2011.00694.x).

Eriks-Brophy, A., A. Durieux-Smith, J. Olds, E. Fitzpatrick, Ch. Duquette \& J. WhitTingham (2006) 'Facilitators and Barriers to the Inclusion of Orally Educated Children and Youth with Hearing Loss in Schools: Promoting Partnerships to Support Inclusion', Volta Review 106(1) 53-88, retrieved 2021 Sep 29 from https://www.proquest.com/openview/a9797b6cf852e57bffec9e993b$42 \mathrm{f} 9 \mathrm{c} 0 / 1$ ?pq-origsite $=$ gscholar\&cbl $=41448$.

Fellinger, J., D. Holzinger \& R. Pollard (2012) 'Mental Health of Deaf People', The Lancet 379(9820), 1037-44 (https://doi.org/10.1016/S0140-6736(11)61143-4).

Galla, B.M., \& A.L. Duckworth (2015) 'More than Resisting Temptation: Beneficial Habits Mediate the Relationship Between Self-Control and Positive Life Outcomes', Journal of Personality and Social Psychology 109(3), 508-25 (https://doi.org/10.1037/pspp0000026).

Garcia-Vesga, M.C. \& E. Domíngues De La Ossa (2013) 'Desarrollo teórico de la Resiliencia y su aplicación en situaciones adversas: Una revisión analítica', Revista Latinoamericana de Ciencias Sociales, Niñez y Juventud 11(1), 63-77 (https://doi.org/10.11600/1692715x.1113300812).

Gardner, T.W., Dishion T.J. \& A.M. Connell (2008) 'Adolescent Self-Regulation as Resilience: Resistance to Antisocial Behavior Within the Deviant Peer Context', Journal of Abnormal Child Psychology 36, 273-84 (https://doi.org/10.1007/ s10802-007-9176-6). 
Gestsdottir, S. \& R.M. Lerner (2008) 'Positive Development in Adolescence: The Development and Role of Intentional Self-Regulation', Human Development 51(3), 202-24 (https://doi.org/10.1159/000135757).

Gilmore, L., M. Campell, I. Shochet, R. Garland, T. Smyth, C. Roberts \& D. West (2014) 'Promoting Resilience in Children with Intellectual Disability: A Randomized Controlled Trial in Australian Schools' in S. PRINCE-EMBURY \& D. SAKLOFSKE, eds., Resilience Interventions for Youth in Diverse Populations (New York: Springer) 353-73 (https://doi.org/10.1007/978-1-4939-0542-3_16). GreenberG, M.T. \& C.A. Kusché (1998) 'Preventive Intervention for School-Age Deaf Children: The PATHS Curriculum', Journal of Deaf Studies and Deaf Education 3(1), 49-63 (https://doi.org/10.1093/oxfordjournals.deafed.a014340).

Hall, P.A. \& G.T. Fong (2007) 'Temporal Self-Regulation Theory: A Model for Individual Health Behavior', Health Psychology Review 1(1), 6-52 (https://doi. org/10.1080/17437190701492437).

Hatamizadeh, N., M. Ghasemi, A. Saeedi \& A. Kazemnejad (2008) 'Perceived Competence and School Adjustment of Hearing Impaired Children in Mainstream Primary School Settings', Child Care Health and Development 34(6), 789-94 (https://doi.org/10.1111/j.1365-2214.2008.00871.x).

Hofer, J., H. Busch \& J. KärTner (2011) 'Self-Regulation and Well-Being: The Influence of Identity and Motives', European Journal of Personality 25(3), 211-24 (https://doi.org/10.1002/per.789).

King, K.M., L.J. Lengua, K.C. Monahan (2013) 'Individual Differences in the Development of Self-Regulation During Pre-adolescence: Connections to Context and Adjustment', Journal of Abnormal Child Psychology 41, 57-69 (https://doi.org/10.1007/s10802-012-9665-0).

Kirman, A. \& H.Y. SARI (2013) 'Health Status of Hearing-Impaired Children and Adolescents', International Journal of Nursing Practice 19(3), 233-40 (https:// doi.org/10.1111/ijn.12071).

Knutson, J.F. \& C.R. LAnsing (1990) 'The Relationship Between Communication Problems and Psychological Difficulties in Persons with Profound Acquired Hearing Loss', Journal of Speech and Hearing Disorders 55(4), 656-64 (https:// doi.org/10.1044/jshd.5504.656).

Krueger, R.F., B.M. Hicks, C.J. Patrick, S.R. Carlson, W.G. Iacono \& M. Mcgue (2002) 'Etiologic Connections among Substance Dependence, Antisocial Behavior and Personality: Modeling the Externalizing Spectrum', Journal of Abnormal Psychology 111(3), 411-24 (https://doi.org/10.1037/0021-843X.111.3.411).

LAKes, K.D. \& W.T. Hoyt (2004) 'Promoting Self-Regulation Through School-Based Martial Arts Training', Journal of Applied Developmental Psychology 25(3), 283-302 (https://doi.org/10.1016/j.appdev.2004.04.002).

LuCKNER, J.L. \& S. MovahedAZARHOUligh (2019) 'Social-Emotional Interventions with Children and Youth Who are Deaf or Hard of Hearing: A Research 
Synthesis', Journal of Deaf Studies and Deaf Education 24(1), 1-10 (https:// doi.org/10.1093/deafed/eny030).

Luckner, J.L. \& A.M. Sebald (2013) 'Promoting Self-Determination of Students Who Are Deaf or Hard of Hearing', American Annals of the Deaf 158(3), 377-86 (http://doi.org/10.1353/aad.2013.0024).

Luthar, S.S., D. Cicchetti \& B. Becker (2000) 'The Construct of Resilience: A Critical Evaluation and Guidelines for Future Work', Child Development 71(3), 543-62 (https://doi.org/10.1111/1467-8624.00164).

Martin, J. \& A.-M. Mclellan (2008) 'The Educational Psychology of Self-Regulation: A Conceptual and Critical Analysis', Studies in Philosophy and Education 27, 433-48 (https://doi.org/10.1007/s11217-007-9060-4).

Martin, A.J., R.J. Collie \& E. Frydenberg (2017) 'Social and Emotional Learning: Lessons Learned and Opportunities Going Forward' in E. FrydenberG, A. Martin, R. Collie, eds., Social and Emotional Learning in Australia and the Asia-Pacific (Singapore: Springer) 459-71 (https://doi.org/10.1007/978981-10-3394-0_24).

Masten, A.S. (1999) 'The Promise and Perils of Resilience Research as a Guide to Preventive Interventions: Comments on Rolf and Johnson: Positive Life Adaptations' in M.D. Glantz \& J. Johnson eds., Resilience and Development: Positive Life Adaptations (New York: Plenum) 251-57, retrieved 1 Oct 2021 from https://experts.umn.edu/en/publications/the-promise-and-perils-of-resilienceresearch-as-a-guide-to-preve.

McCarthy-Jones, S. \& C. Fernyhough (2011) 'The Varieties of Inner Speech: Links Between Quality of Inner Speech and Psychopathological Variables in a Sample of Young Adults', Consciousness and Cognition 20(4), 1586-93 (https://doi.org/10.1016/j.concog.2011.08.005).

Miller, R.B. \& S.A. Brickman (2004) 'A Model of Future Oriented Motivation and Self-Regulation', Educational Psychology Review 16, 9-33 (https://doi. org/10.1023/B:EDPR.0000012343.96370.39).

Minnaert A., A. Prince \& M.C. Opdenakker (2017) 'The Effect of Self-Regulated Strategy Instruction and Behavioral Consultation on Motivation: A Longitudinal Study on the Effect of School-Based Interventions in Secondary Education', Frontiers in Education 2, 61 (https://doi.org/10.3389/feduc.2017.00061).

Mischel, W., Y. ShodA, P.K. PeAKe (1988) 'The Nature of Adolescent Competencies Predicted by Preschool Delay of Gratification', Journal of Personality and Social Psychology 54(4), 687-96 (https://doi.org/10.1037/0022-3514.54.4.687).

Moffitt, T.E., L. Arseneault, D. Belsky, N. Dickson, R.J. Hancox, H.L. Harrington, R. Houts, R. Poulton, B.W. Roberts, S. Ross, M.R. Sears, W.M. Thomson \& A. CAspi (2011) 'A Gradient of Childhood Self-Control Predicts Health, Wealth, and Public Safety', Proceedings of the National Academy of Sciences of the United States of America 108(7), 2693-98 (https://doi.org/10.1073/pnas.1010076108). 
Moilanen, K.L. (2007) 'The Adolescent Self-Regulatory Inventory: The Development and Validation of a Questionnaire of Short-Term and Long-Term Self-Regulation', Journal of Youth and Adolescence 36, 835-48 (https://doi. org/10.1007/s10964-006-9107-9).

Moores, D.F. (2001) Educating the Deaf: Psychology, Principles and Practices ( $4^{\text {th }}$ ed.; Boston: Houghton Mifflin) retrieved 1 Oct 2021 from http://file.upi. edu/Direktori/FIP/JUR__PEND._LUAR_BIASA/197004171994022-IMAS DIANA_APRILIA/RINGKASAN_1.pdf.

Murray, D.W., K. Rosanbalm \& C. Christopoulos (2016) Self-Regulation and Toxic Stress Report 3: A Comprehensive Review of Self-Regulation Interventions from Birth Through Young Adulthood (OPRE Report 2016-34) (Washington: Office of Planning, Research and Evaluation, Administration for Children and Families, U.S. Department of Health and Human Services) retrieved 1 Oct 2021 from https://fpg.unc.edu/publications/self-regulation-and-toxic-stress-report-3-comprehensive-review-self-regulation.

Murray, D.W., K. Rosanbalm, C. Christopoulos \& A. Hamoudi (2015) Self-Regulation and Toxic Report 1: Foundations for Understanding Self-Regulation from an Applied Perspective (OPRE Report \#2015-21) (Washington: Office of Planning, Research and Evaluation, Administration of Children and Families, US Department of Health and Human Services) retrieved 1 Oct 2021 from https://www.acf.hhs.gov/sites/default/files/documents/report_1_foundations_paper_final_012715 submitted 508_0.pdf.

NeAl, D.J. \& K.B. CAREY (2005) 'A Follow-Ūp Psychometric Analysis of the Self-Regulation Questionnaire', Psychology of Addictive Behaviors 19(4), 414-22 (https://doi.org/10.1037/0893-164X.19.4.414).

Nunes, A.D., C.R. Silva, S.A. Balen, D.L. Souza, I.R. Barbosa (2019) 'Prevalence of Hearing Impairment and Associated Factors in School-Aged Children and Adolescents: A Systematic Review', Brazilian Journal of Otorhinolaryngology 85(2), 244-53 (http://doi.org/10.1016/j.bjorl.2018.10.009).

Oriol, X., R. Miranda, J.C. Oyanedel \& J. Torres (2017) 'The Role of Self-Control and Grit in Domains of School Success in Students of Primary and Secondary School', Frontiers in Psychology 8, 1716 (https://doi.org/10.3389/ fpsyg.2017.01716).

Pandey, A., D. Hale, S. Das, A.-L. Goddings, S.-J. Blakemore, \& R.M. Viner (2018) 'Effectiveness of Universal Self-Regulation-Based Interventions in Children and Adolescents: A Systematic Review and Meta-Analysis', JAMA Pediatrics 172(6), 566-75 (https://doi.org/10.1001/jamapediatrics.2018.0232).

Quigley, S.P. \& V.P. PAul (1994) Language and Deafness: Study Guide (San Diego: Singular).

Rimm-Kaufman, S.E. \& Y-J. I. Chiu (2007) 'Promoting Social and Academic Competence in the Classroom: An Intervention Study Examining the Contribution 
of the Responsive Classroom Approach', Psychology in the Schools 44(4), 397-413 (https://doi.org/10.1002/pits.20231).

Rimm-Kaufman, S.E, M.D. Storm, B.E. Sawyer, R.C. Pianta \& K.M. LaParo (2006) 'The Teacher Belief Q-Sort: A Measure of Teachers' Priorities in Relation to Disciplinary Practices, Teaching Practices, and Beliefs About Children', Journal of School Psychology 44(2), 141-65 (https://doi.org/10.1016/j.jsp.2006.01.003). Rosa, O.M.A. \& L.M. Villar Angulo (2019) 'Attitudes of Children with Hearing Loss towards Public Inclusive Education', Education Sciences 9(3), 244-56 (https://doi.org/10.3390/educsci9030244).

Rutter, M. (1985) 'Resilience in the Face of Adversity: Protective Factors and Resistance to Psychiatric Disorder', British Journal of Psychiatry 147(6), 598-611 (https://doi.org/10.1192/bjp.147.6.598).

Rutter, M. (2012) 'Resilience as a Dynamic Concept', Development and Psychopathology 24(2), 335- 44 (https://doi.org/10.1017/S0954579412000028).

Sawyer, A.C.P., C.R. Chittleborough, M.N. Mittinty, L.R. Miller-Lewis, M.G. SAWYeR, T. SulLIVAN \& J.W. LYNCH (2014) 'Are Trajectories of Self-Regulation Abilities from Ages 2-3 to 6-7 Associated with Academic Achievement in the Early School Years?', Child: Care, Health and Development 41(5), 744-54 (https://doi.org/10.1111/cch.12208).

Seligman, M.E.P., R.M. Ernst, J. Gillham, K. Reivich \& M. Linkins (2009) 'Positive Education: Positive Psychology and Classroom Interventions', Oxford Review of Education 35(3), 293-311 (https://doi.org/10.1080/0305498090293 4563).

Shargorodsky, J., S.G. Curhan, G.C. Curhan \& R. Eavey (2010) 'Change in Prevalence of Hearing Loss in US Adolescents', JAMA 304(7), 772-78 (https:// doi.org/10.1001/jama.2010.1124).

Shochet, I., A. Wurfl \& R. Hoge (2004) 'The Resourceful Adolescent Programs: Working with Teenagers in Queensland, Australia' in Mental Health Promotion: Case Studies from Countries (Switzerland: WHO and World Federation for Mental Health) 10-12.

Smith, S.W., A.P. Daunic, J. Algina, D.L. Pitts, K.L. Merrill, M.M. Cumming \& C. AlLEN (2017) 'Self-Regulation for Students with Emotional and Behavioral Disorders: Preliminary Effects of the I Control Curriculum', Journal of Emotional and Behavioral Disorders 25(3), 143-56 (https://doi.org/10.1177/1063426616661702).

Soleimanieh Naeini, T., F. Keshavarzi Ashadi, N. Hatamizadeh \& E. BaKhshi (2013) 'The Effect of Social Skills Training on Perceived Competence of Female Adolescents with Deafness', Iran Red Crescent Medical Journal 15(12), e5426 (https://doi.org/10.5812/ircmj.5426).

Stevenson, J., J. Kreppner, H. Pimperton, S. Worsfold \& C. Kennedy (2015) 'Emotional and Behavioral Difficulties in Children and Adolescents with Hear- 
ing Impairment: A Systematic Review and Meta-Analysis', European Child \& Adolescent Psychiatry 24, 477-96 (https://doi.org/10.1007/s00787-015-0697-1). Stevenson, J., H. Pimperton, J. Kreppner, S. Worsfold, E. Terlektsi \& C. Kennedy (2017) 'Emotional and Behavior Difficulties in Teenagers with Permanent Childhood Hearing Loss', International Journal of Pediatric Otorhinolaryngology 101, 186-95 (https://doi.org/10.1016/j.ijporl.2017.07.031). Sullivan, G.M. \& R. FeInN (2012) 'Using Effect Size-Or Why the P Value Is Not Enough', Journal of Graduate Medical Education 4(3), 279-82 (https://doi. org/10.4300/JGME-D-12-00156.1).

Tominey, S.L. \& M.M. Mcclelland (2011) 'Red Light, Purple Light: Findings from a Randomized Trial Using Circle Time Games to Improve Behavioral Self-Regulation in Preschool', Early Education \& Development 22(3), 489-519 (https://doi.org/10.1080/10409289.2011.574258).

Tye-Murray, N., S. Hale, B. Spehar, J. Myerson \& M.S. Sommers (2014) 'Lipreading in School-Age Children: The Roles of Age, Hearing Status, and Cognitive Ability', Journal of Speech, Language, and Hearing Research 57(2), 556-65 (https://doi.org/10.1044/2013_JSLHR-H-12-0273).

Vallotton, C., C. Ayoub (2011) 'Use Your Words: The Role of Language in the Development of Toddlers' Self-Regulation', Early Childhood Research Quarterly 26(2), 169-81 (https://doi.org/10.1016/j.ecresq.2010.09.002).

Vostanis, P., M. Hayes, M. Du Feu, J. Warren (2007) 'Detection of Behavioral and Emotional Problems in Deaf Children and Adolescents: Comparison of Two Rating Scales', Child: Care, Health and Development 23(3), 233-46 (https:// doi.org/10.1111/j.1365-2214.1997.tb00966.x).

Vygotsky, L.S. (1962) 'Thought and Word' in L.S. Vygotsky \& E. Hanfmann, G. VAKAR, eds., Thought and Language. Studies in communication (Cambridge: MIT) 119-53 (https://doi.org/10.1037/11193-007).

Westhues, A., A. S. Hanbidge, R. Gebotys, \& A. Hammond (2009) 'Comparing the Effectiveness of School-Based and Community-Based Delivery of an Emotional Regulation Skills Program for Children', School Social Work Journal 34(1), 74-95, retrieved 1 Oct 2021 from https:/eric.ed.gov/?id=EJ893730.

Wong, M.M. \& M. Csikszentminalyi (1991) 'Motivation and Academic Achievement: The Effects of Personality Traits and the Duality of Experience', Journal of Personality 59(3), 539-74 (https://doi.org/10.1111/j.1467-6494.1991.tb00259.x).

World Health Organization (2012) WHO Global Estimates on Prevalence of Hearing Loss retrieved 1 Oct 2021 from https:/www.who.int/pbd/deafness/ WHO_GE_HL.pdf.

Zimbardo, P.G. \& J.N. Boyd (1999) 'Putting Time in Perspective: A Valid, Reliable Individual-Differences Metric', Journal of Personality and Social Psychology 77(6), 1271-88 (https://doi.org/10.1037/0022-3514.77.6.1271). 
Zimmer-Gembeck, M.J. \& E.A. Skinner (2008) 'Adolescents Coping with Stress: Development and Diversity', The Prevention Researcher 15(4), 3-7, retrieved 1 Oct 2021 from https://eric.ed.gov/?id=EJ823350.

Zimmer-Gembeck, M.J. \& E.A. Skinner (2011) 'The Development of Coping Across Childhood and Adolescence: An Integrative Review and Critique of Research', International Journal of Behavioral Development 35(1), 1-17 (https://doi. org/10.1177/0165025410384923).

Zimmerman, B.J. (1995) 'Self-Regulation Involves More than Metacognition: A Social Cognitive Perspective', Educational Psychologist 30(4), 217-21 (https:// doi.org/10.1207/s15326985ep3004_8).

Zimmerman, K. \& P. Brugger (2013) 'Signed Soliloquy: Visible Private Speech', Journal of Deaf Studies and Deaf Education 18(2), 261-70 (https://doi. org/10.1093/deafed/ens072).

Zolkoski, S.M. \& L.M. Bullock (2012) 'Resilience in Children and Youth: A Review', Children and Youth Services Review 34(12), 2295-2303 (https://doi. $\operatorname{org} / 10.1016 / j$.childyouth.2012.08.009). 